\title{
Denetim Planlaması Aşamasında Analitik İnceleme Tekniği Olarak Yapay Sinir Ağları Kullanımı: Bir Firma Uygulaması
}

\author{
Using of Artificial Neural Networks As an Analytical Investigation Technique at Audit \\ Planning Stage: A Company Application
}

Meltem KARAATLI' , Serpil SENAL ${ }^{2}$, Mahmut Sami ÖZTÜRK ${ }^{3}$

\begin{abstract}
ÖZET
Bu araştırmanın amacı, bağımsız denetim sürecinin planlama aşamasında analitik inceleme tekniği olarak yapay sinir ağı yönteminin kullanımının gösterilmesidir. Bu bağlamda çalışmada, denetim süreci, analitik inceleme prosedürü ve tekniklerinden bahsedilmekte ve yapay sinir ağlarının denetçiye ve denetim sürecine sağladığı kolaylıklar ortaya konulmaktadır. Borsa İstanbul'da imalat sektöründe işlem gören bir işletmenin Mart 2004-Aralık 2012 dönemindeki denetimden geçmiş 8 yıllık finansal tabloları kullanılmaktadır. Çalışmanın sonucunda yapay sinir ağları yönteminin iyi bir tahmin aracı olduğu görülmektedir.
\end{abstract}

Anahtar Kelimeler: Yapay sinir ağları, bağımsız denetim, analitik inceleme prosedürü.

\section{GiRiş}

Finansal tablolar, ekonomik hayatın vazgeçilmez unsurlarından biri olan işletmelerle ilgili bilgi gereksinimlerinin karşılanmasında önemli birer araçtır. İşletme içinde ve dışında yer alan çıkar grupları, işletmeyle ilgili ekonomik kararların alınmasında finansal tablolara gereksinim duymaktadırlar. İşletmenin finansal tabloları aracılığı ile alınacak kararların isabet derecesi ise, bu finansal tablolarda yer alan bilgilerin doğruluğu ve güvenilirliği ile sağlanmaktadır. (Dönmez vd., 2011:121). Amerikan Diplomalı Hile Araştırmacıları Derneği'nin tüm dünya ülkelerinde yapmış olduğu araştırmaya göre, dünyada hileli finansal raporlama nedeniyle oluşan kayıpların yılda ortalama 2.9 Trilyon dolardan fazla olduğu tespit edilmiştir (ACFE, 2010: 2-5, Usta vd., 2011:14). Dünyada yaşanan Enron ve Parmalat gibi skandallar da bugün bağımsız denetimin ne kadar önemli olduğunun göstergesidir. Bu nedenle son yıllarda söz konusu skandalları ve kayıpları yaşamamak adına denetim sürecinin belirli aşama-

\begin{abstract}
The purpose of this research is, the application of artificial neural network technique at planning stage of independent audit process. In this respect, auditing process, analytical investigation procedures and techniques are mentioned and the conveniences of artificial neural networks for auditor and audit process are exhibited. The controlled financial statements of a corporation which is treated in manifacturing sector at Borsa Istanbul, for 8 years period of March 2004 and December 2012 are used. At the end of the study it is noticed that, artificial neural network technique made a good estimation.
\end{abstract}

Keywords: Artificial neural networks, independent audit, analytical investigation procedure.

larında analitik inceleme prosedürü ve tekniklerinin daha etkin kullanımı söz konusudur.

Analitik inceleme prosedürü denetçiye daha fazla soruşturmaya ihtiyaç olup olmadığı ile ilgili sinyal vermektedir (Busto,1998:356-357). Finansal ve finansal olmayan bilgiler arasındaki ilişkinin makul olup olmadığı ile ilgili çalışmanın yapıldığı bir değerlendirme sürecidir (http://www.padillacpa.com). Bununla birlikte, finansal tablolarda yer alan verilerin karşılaştırıması ve aralarındaki ilişkilerin araştırılarak gözden geçirilmesidir. Bu tür işlemler, "uygunluğu araştırmaya yönelik denetim işlemleri" niteliğinde olup amacı, veriler arasında anlamlı ilişkilerin var olduğunu doğrulamak ve bunlar arasında olağan kabul edilmeyecek sapmaları bulup ortaya çıkarmaktır (Güredin, 2008:187). Bu bağlamda, analitik inceleme süreci hile riskinin yüksek olduğu alanların tespitinde ve analitik inceleme sürecinin sonunda elde edilen verilerle beklentilerin karşılaştırılması, denetim prosedürlerinin kapsamını belirlemede denetçiye büyük kolaylıklar

\footnotetext{
${ }^{1}$ Yrd. Doç. Dr., Süleyman Demirel Üniversitesi, İktisadi ve İdari Bilimler Fakültesi, İşletme Bölümü, meltemkaraatli@sdu.edu.tr 
sağlamaktadır (Şirin, www.hazine.org.tr,:65). Analitik inceleme sürecinde birçok teknik kullanılmaktadır. Çalışmada iyi bir tahminleme yöntemi olması nedeniyle analitik inceleme tekniği olarak yapay sinir ağları kullanılmıştır. Çalışmanın amacı, yapay sinir ağı modelinin analitik inceleme sürecindeki kullanımının ve diğer tekniklere göre sağlayacağı avantajların geliştirilecek bir model yardımı ile ortaya konulmasıdır. Birçok alanda yapay sinir ağı modelinin kullanılması ve iyi sonuçlar elde edilmesine rağmen denetim alanında bu modelden faydalanılmaması çalışmanın konusunu belirlemede etkili olmuştur. Bu kapsamda, çalışmada öncelikle bağımsız denetim süreci ve analitik incelemenin denetim süreci içerisindeki yerinden bahsedilmiştir. Özellikle analitik incelemeye denetim sürecinin hangi aşamalarında ve hangi amaçlarla başvurulduğuna değinilmiştir. Bunun yanında, çalışmada analitik inceleme sürecinde kullanılan teknikler, yapay sinir ağı modeli ile karşılaştırmalı olarak incelenmiştir. Çalışmanın son bölümünde ise denetimin planlama aşamasında yapay sinir ağları modelinin analitik inceleme tekniği olarak kullanımı ve sonuçları bir firma üzerinde uygulamalı olarak gösterilmiştir. Analitik inceleme tekniklerinin denetimin birçok aşamasında kullanılabilmesine rağmen çalışmada denetimin planlama aşamasında kullanımı tercih edilmiştir. Çünkü denetimin planlanması aşamasında kullanılan analitik inceleme teknikleri denetim prosedürlerinin kapsamının belirlenmesinde denetçiye büyük kolaylıklar sağlamaktadır.

Çalışmada Borsa İstanbul'da imalat sektöründe işlem gören bir işletmenin 8 yıllık denetimden geçmiş finansal tablolarından yararlanılmış ve işletmenin belli bir dönemine ait hesap bakiyelerini tahmin edebilecek bir yapay sinir ağı modeli geliştirilmiştir. Ayrıca modeli test etmek amacıyla, 2013 yılı Mart ayına ait hesap bakiyeleri tahmin edilmiştir. 2013 yılı Nisan ayında işletmenin finansal tablolarının yayınlanması ile birlikte modelin tahminleri işletmenin finansal tablosunda beyan ettiği hesap bakiyeleri ile karşılaştırılarak tutarsızlıklar incelenmiştir. Çalışmanın sonucunda, yapay sinir ağlarının analitik inceleme sürecinde denetçiye çok büyük kolaylıklar sağladığı görülmüştür. Denetçi söz konusu model yardımıyla, öncelikle olması gereken hesap bakiyelerini belirlemekte ve işletme tarafından beyan edilen hesap bakiyeleri ile karşılaştırarak tutarsız hesap bakiyelerini kolaylıkla belirleyebilmektedir. Böylece hile ya da hata riskinin yüksek olduğu alanların tespiti dolayısı ile denetim prosedürlerinin kapsamının belirlenmesinde denetçiye büyük bir kolaylık sağlamaktadır.

\section{BAĞIMSIZ DENETIMDE ANALITIK INCELEME SÜRECI}

Bağımsız denetim sürecinde denetçinin rolü, finansal tabloların güvenilirliğini değerlendirmektir. Bu sürecin tamamlanabilmesi için denetçiler bir takım analitik inceleme prosedürlerine başvurmaktadır (Busto,1998:356-357). Son yıllarda analitik inceleme prosedürleri denetçiler ve akademisyenler tarafından sıklıkla incelenen konulardan birisi olmuştur. Bunun büyük ölçüde sebebi, denetçilerin denetimin kalitesinden ödün vermeksizin denetim maliyetlerini düşürme çabasıdır. Denetim süresini azaltması ve bu yolla maliyet tasarrufu sağlaması analitik inceleme prosedürlerine ve bu süreçte kullanılan tekniklere olan ihtiyacı artırmaktadır. Bunun yanında risk temelli denetim analitik inceleme tekniklerinin önemini daha da artırmıştır. Çünkü söz konusu teknikler denetçinin risk tespitine de yardımcı olmaktadır (Samaha vd.,2009:883).

Denetim standartlarından Mesleki Standartlar, müşteri seçiminden, bir denetim çalışmasının planlanması ve raporun yazılmasına kadarki tüm aşamalarda denetim riskinin dikkate alınmasını gerekli kılmaktadır. Son yıllarda yaşanan denetim skandalları ve denetim davalarındaki artışlar denetçileri risk yönetimine yönlendirmektedir (Huss vd.,2000:113-122, Davutyan vd, 1997:87). Denetim süreci ile ilgili olarak iki risk söz konusudur. Bunlar denetim riski ve işletme riskidir. İşletme riski; finansal tabloların denetimi ile ilişki olarak, denetçinin veya denetim şirketinin bir davadan veya söylentiden dolayı meslek uygulamasının zarar görmesi veya kayba uğraması riskidir (Kepekçi, 2004: 46). Denetim riski ise, mali tablolarda önemli yanlışılılar olduğu halde denetçinin mali tabloların doğru olarak sunulduğu sonucuna varması ve mali tablolar hakkında olumlu görüş bildirmesi olasılığıdır. Bu risk unsuru genel olarak bir hesap kalanının veya işlem türünün tamamının denetçi tarafından denetlenme durumlarında var olan belirsizlikten, denetçinin uygun olmayan denetim prosedürlerini seçmesinden veya uygun bir prosedürü yanlış uygulamasından dolayı ortaya çıkabilmektedir (Kepekçi, 2004:45-47).

Analitik inceleme prosedür ve tekniklerine denetim sürecinin değişik safhalarında başvurulabilinmektedir. Denetimin planlaması safhasında mı, denetimin yürütülmesi safhasında $\mathrm{ml}$, ya da denetim raporunun tamamlanmasından hemen önce mi başvurulacağı denetçinin amacına bağlıdır. Amaç, denetim sırasında uygulanacak denetim işlemlerinin türünün, niteliğinin, kapsamının ve uygulama zaman ve sırasının belirlenmesi olduğunda, denetçi analitik inceleme yöntemine denetim planlaması safhasında başvurmaktadır (Güredin, 2008:187). 
Analitik inceleme prosedürü yardımıyla işletmenin sektördeki durumunu, geçmiş yıl verilerine göre cari yıldaki gelişimini ortaya koymak mümkün olmaktadır. Satış karlılığı ve maliyet oranlarına bakılarak işletmenin envanter hesaplamalarında bir düzensizlik olup olmadığına karar verilebilir ve stokların incelenmesinde daha ayrıntılı denetim testlerinin uygulanmasına gerek duyulabilir. Analitik inceleme prosedürü ile yapılan incelemeler sonucu olağanüstü durumlara rastlanmazsa, bu alanlarda yapılacak diğer denetim çalışmaları azaltılır veya hiç uygulanmaz. Örneğin, işletmenin cari yıldaki ilk üç aylık komisyon giderlerine uygulanacak analitik inceleme prosedürleri önemli bir dalgalanma ortaya koymazsa, bu hesap daha sonra fazla önemsenmez veya hiç incelenmez (Bozkurt,1998:154).

Denetimin planlama aşamasında yapılan analitik incelemeler, denetçinin müşteri işletmeyi ve işletme çevresini tanımasını sağlamaktadır. Bununla birlikte analitik inceleme sürecinin sonuçları, denetçinin iş- letme ile ilgili değerlendirmesi gereken risk alanlarını belirlemesine de yardımcı olmaktadır (http://www. padillacpa.com). Uluslararası Denetim Standardı 520 Analitik Prosedürler Standardında da belirtildiği üzere, analitik prosedürler sonucu, önemli dalgalanmalar ya da diğer ilgili bilgilerle olan tutarsızlıklar tespit edildiğinde ya da tahmini miktarlardan sapmalar belirlendiğinde, denetçi araştırma yapmalı ve yeterli açıklamayı ve buna uygun kesin kanıtı elde etmelidir (TUDESK, 2008:446).

Analitik inceleme prosedürleri hesap bakiyelerinin doğrulanması amacıyla denetimin test aşamasında da kullanılabilmektedir. Bu testler genellikle diğer denetim prosedürleri ile birlikte kullanılır. Analitik inceleme prosedürlerinin sağladığı güvence ilişkilerin tahmin edilebilirliğine bağlıdır. Denetim sürecinin son aşaması olan rapor aşamasından önce yapılan analitik incelemeler ise, denetçinin raporunda objektif bir karar almasına yardımcı olmaktadır (Arens vd., 2011:225).

Tablo1: Denetimin Amacına Göre Analitik İnceleme Prosedürlerinin Kullanımı

\begin{tabular}{|l|c|c|c|}
\hline Denetim amacı & Planlama & Test & Tamamlanma \\
\hline $\begin{array}{l}\text { Müşteri işletmeyi ve işletmenin içinde bulunduğu } \\
\text { endüstriyi anlamak }\end{array}$ & $\mathrm{X}$ & & \\
\hline Işletmenin sürekliliğini değerlendirmek & $\mathrm{X}$ & & $\mathrm{X}$ \\
\hline Mümkün olabilecek hataları tespit etmek & $\mathrm{X}$ & $\mathrm{X}$ & $\mathrm{X}$ \\
\hline Yapılacak detaylı test miktarını azaltmak & $\mathrm{X}$ & $\mathrm{X}$ & \\
\hline
\end{tabular}

( Kaynak: Koskivaara, 2004: 194)

Analitik inceleme prosedürlerinin kullanımında önemli olan amaca en uygun prosedürün seçilebilmesidir. Denetçinin durumuna göre kullanabileceği analitik inceleme prosedürleri beş ana grupta toplanabilir (Bozkurt,1998:155):

- İşletme verileri ile sektör verilerinin karşılaştırılması,

- İşletme verileri ile önceki yıllara ait benzer verilerin karşılaştırılması,

- Işsletme verileri ile işletme tarafından belirlenmiş beklenen sonuçların karşılaştııılması,

- Işletme verileri ile denetçi tarafından belirlenmiş beklenen sonuçların karşılaştııılması,

- Işsletme verileri ile finansal olmayan verilerin ortaya koyduğu beklenen sonuçların karşılaştırılması.

Çift taraflı kayıt sisteminde hesaplar arasında karşılıklı iliş̧i vardır. Bir hesaptaki artış diğerinde azalmaya neden olur. İlgili hesaplar arasındaki mutabakat, en azından hesaplarda mekanik bir hatanın olmadığına dair bir delildir. Aralarında ilişki bulunan bazı hesaplar şu şekilde özetlenebilir (Gürbüz, 1995:111):
- Amortisman giderleri, birikmiş amortismanlar ve sabit varlıklar,

- Satış iadesi ve satış iskontosu, pazarlama satış dağıtım gideri-satışlar,

- Fireler- satılan malın maliyeti,

- Faiz giderleri, borç senetleri, tahviller, banka kredileri,

- Satışlar, satılan malın maliyeti,

- Satışlar, ticari alacaklar,

- Üretim miktarı, personel giderleri, makine maliyeti, verim

- Satışlar, hesaplanan KDV,

- Satışlar, kasa, banka,

- Kar marjı, satışlar stokların ve satılan malın maliyeti.

Analitik inceleme sürecinde denetçi öncelikle, işletmenin beyan ettiği hesap bakiyelerinin doğruluğunu tespit etmek amacıyla hesap bakiyeleri için kendi beklentilerini belirlemektedir. Bunun için denetçi hesap bakiyeleri ile ilgili olarak öncelikle olması gereken tutarları tahmin etmeye çalışır. Müşteri firmanın beyan ettiği hesap bakiyeleri ile karşılaştırılarak orta- 
ya çıkan farklııklar incelenir. Ortaya çıkan farklılığın kabul edilebilirliği, denetçinin belirlediği önemlilik ve güven düzeyinden etkilenir (Puttick vd.,2008:533).

Analitik inceleme prosedürlerinin uygulanması aşamasında denetçinin kullanacağı birden fazla analitik inceleme tekniği bulunmaktadır. Mali tablolardaki kalemlerin zaman içerisinde gösterdikleri eğilimleri incelemek için trend analizi kullanılır. Oran analizi, mali tablolarda yer alan iki kalem arasındaki ilişkinin matematiksel ifadesidir. Mali tablolarda yer alan tutarların nispi ilişkileri incelenerek işletmenin mali durumu konusunda bilgi edinilir (Çabuk vd., 2008:174). Regresyon analizi, formüle edilmiş bir model yardımı ile çevresel ve ekonomik faktörleri de dikkate alarak finansal ve ekonomik verilerin tahmininde kullanımaktadır. Yapay sinir ağları ise, denetçinin beklenen bir değer yaratmasını sağlarken aynı zamanda oluşturulan bu beklenen değer ile müşteri işletme tarafından oluşturulan değer arasında karşılaştırma yapmasına olanak sağlamaktadır (Koskivaara, 2004:192).

Analitik inceleme sürecinde kullanılan diğer bir teknik ise uzman sistemlerdir. Uzman sistemler, bir uzmanın uzmanlık bilgisini bilgisayar ortamında gerçekleştirmeyi amaçlayan bilgisayar programıdır (Bilge, 2008: 113).

Yapay sinir ağının diğer tekniklere göre birçok avantajı bulunmaktadır. Yapay sinir ağları mevcut veriler arasındaki ilişkiyi öğrenerek, yeni bir durumla karşılaştığında genelleme yapabilme özelliğine sahip bir yöntemdir. Regresyon analizinde olduğu gibi, yapay sinir ağlarında önceden oluşturulmuş bir modele ihtiyaç bulunmamaktadır. Ayrıca diğer istatistik tekniklerinden farklı olarak yapay sinir ağlarının doğrusal olmayan ilişkileri de tanımlayabilme özelliği bulunmaktadır (Koskivaara, 2004:192). Uzman sistemlerde ise tümden gelim mantığı var iken yapay sinir ağında tümevarım mantığı bulunmaktadır. Uzman sistemlerde uzman veya analizci tarafından tanımlanan kurallar serisine uyulması durumunda sonuca ulaşılabilirken, yapay sinir ağları deneme yanılma yoluyla girdi ve çıktı arasındaki ilişkinin fonksiyonunu tanımlar. Bununla birlikte, öngörülemeyen bir durum olması durumunda, yapay sinir ağları esnek bir yapıya sahip olması nedeniyle, bu duruma uyum gösterebilirken uzman sistemler için bu söz konusu değildir (Okab vd., 2012:54).

2007 yılı itibari ile Sermaye Piyasası Kurulu'ndan bağımsız denetim yetkisi alan 32 denetim firmasına yapılan saha araştırması sonucuna göre, denetçilerin en çok başvurduğu analitik inceleme prosedürünün "işletme cari dönem verileri ile önceki dönemlere ait işletme verilerinin karşılaştırılması" olduğu tespit edil- miştir. Bununla birlikte söz konusu analitik inceleme prosedürü için en sık kullanılan tekniğin ise karşılaştırmalı tablolar analizi tekniği olduğu, yapay sinir ağlarına ise çok nadiren başvurulduğu belirlenmiştir (Dönmez vd., 2011: 137).

\section{LITERATÜR INNCELEMESI}

Literatürde muhasebe, finans ve denetim alanında yapılan çalışmalar incelendiğinde, yapay sinir ağlarının genellikle finansal başarısızlıkların ve iflasın tahmininde kullanıldığı tespit edilmiştir. Küçükkocaoğlu ve diğerleri, (2009) çalışmalarında finansal bilgi manipülasyonunu tespit edebilmek amacıyla yapay sinir ağlarından faydalanmışlardır. Wei-Sen ve Yin Kuan, (2009) yapay sinir ağlarını işletme iflaslarının tahmininde kullanmışlardır. Kutlu ve Bodur,(2009) çalışmalarında ileri beslemeli yapay sinir ağı tekniği ile IMKB endeksini tahmin etmeyi amaçlamışlardır.

Finans alanı yanında denetim alanında da yapay sinir ağlarından faydalanıldığı görülmektedir. Etherdige ve diğerleri,(2000) çalışmalarında, müşteri işletmenin finansal pozisyonunu tahmin etmek amaciyla yapay sinir ağı modeline başvurmuştur. Çalışmada üç yapay sinir ağı karşılaştırılmalı olarak kullanılmıştır. 1139 bankadan elde edilen finansal oranlar girdi olarak kullanılmıştır.

Yılancı ve diğerleri, (2008) çalışmalarında, işletmelerin kontrol risk düzeylerinin belirlenebilmesi için yapay sinir ağlarından faydalanarak karar destek aracı geliştirmişlerdir. Çalışmada anket yöntemi ile işletmelerin iç kontrol bilgileri toplanmıştır. Bu bilgiler doğrultusunda, işletmelerin iç kontrol risk düzeyleri belirlenmeye çalışılmış ve denetçilerden elde edilen görüşlerle tahminlerin doğruluğu karşılaştırılmıştır. Benzer bir çalışma Hsueh ve diğerleri, (2009) tarafından yapılmıştır. Söz konusu çalışmada işletmelerin hileli işlemlerde bulunma riski incelenmiştir. Çalışmada öncelikle iç kontrol sistemi ile ilişkili hile risk faktörlerinin tespiti için Big 4 olarak isimlendirilen dört büyük denetim firmasında çalışan denetçilerin görüşlerinden faydalanılmış ve 27 risk faktörü tespit edilmiştir. Bu doğrultuda içerik analizi yöntemi yardımı ile değişkenler tespit edilmiştir. Çalışmanın sonucunda işletmenin finansal istikrarının ve muhasebe yapısının bozulduğu anlarda hile riskinin yüksek olduğu tahmin edilmiştir.

Gaganis ve diğerleri, (2007) çalışmalarında olasılıksal yapay sinir ağı modelini kullanarak denetçinin raporunda bildireceği görüş tipini tahmin etmeye çalışmışlardır. Bunun için çalışmada 1997-2004 yıllarını kapsayan 881 işletmenin finansal tabloları yardımıyla işletme ile ilgili finansal ve finansal olmayan bilgilerden faydalanılmıştır. Söz konusu veriler doğrultusun- 
da çalışmada denetim firma büyüklüğü, müşteri işletmenin firma büyüklüğü ve yer aldığı sektör, müşteri işletmenin personel verimliliği ve personel devir hızı başta olmak üzere 27 değişken kullanılmıştır. Çalışmanın sonucunda olasılıksal yapay sinir ağı modelinden elde edilen tahmini sonuçların doğruluğu, ileri beslemeli yapay sinir ağı yapısı ve lojistik regresyon modelinin sonucu ile karşılaştırılmıştır. Olasılıksal yapay sinir ağı yapısının söz konusu diğer modellere göre daha iyi tahminler yaptığı tespit edilmiştir. Omid ve diğerleri, (2012) de benzer bir çalışma yapmışlardır. Çalışmada denetçinin raporunda bildireceği görüş ve hazırlayacağı raporun türünü tahmin etmek amacıyla çok katmanlı yapay sinir ağı modeli, olasılıksal yapay sinir ağı modeli, radyal temelli fonksiyonlar ve lojistik regresyondan faydalanılarak en iyi sonucu elde edecek bir model geliştirilmesi amaçlanmıştır. Söz konusu çalışmanın sonucunda da Gaganis ve diğerlerinin çalışmalarına benzer sonuçlar elde edilmiştir.

Koskivaara, (2004) ise çalışmasında, yapay sinir ağlarının analitik inceleme sürecinde de kullanılabileceğini böylece analitik inceleme sürecinin denetçiler için daha kolay ve verimli geçeceğini ifade etmiştir. Çalışmada ayrıca denetimin planlama, test ve rapor yazma aşamasında da analitik inceleme prosedürlerinden faydalanılabileceğinden bahsedilmiştir.

Maria ve diğerleri, (2010) yapmış oldukları çalışmada, finansal raporlardaki hile riskini tahmin etmek amacıyla çok katmanlı yapay sinir ağı modelini kullanmışlardır. Çalışmada, öncelikle bağımsız denetçilere bir anket çalışması yöneltilmiş ve hileli finansal raporlara rastladıkları işletmeler ile ilgili bilgiler toplanmaya çalışılmıştır. Buna göre, anket çalışmasında denetçilere, işletmenin yer aldığı sektör, işletmenin büyüklüğü, işletmede denetim komitesinin mevcut olup olmadığı, işletme yöneticisin mevcut konumundaki tecrübesi, yönetimin işletme üzerindeki ortaklık payı ile ilgili sorular yöneltilmiştir. Verilen cevaplar yardımıyla, hileye başvuran şirketlerin özellikleri ortaya konulmuş ve oluşturulan yapay sinir ağı modeli yardımıyla hile riski olan finansal raporlar tahmin edilmiştir. Lin ve Diğerleri de (2003) çalışmalarında, finansal raporlardaki manipülasyonları ortaya çıkarmak amacıyla bulanık yapay sinir ağı modelinden faydalanmıştır. Çalışmada manipülasyonları tahmin etmek amacıyla şüpheli alacaklar için ayrılan karşılıklardaki değişim, toplam alacaklar içerisinde şüpheli alacakların yüzdesi ve toplam varlıklar içerisinde şüpheli alacakların yüzdesi gibi oranlardaki değişimler incelenmiştir.

Yapay sinir ağı modeli ile ilgili literatürde yer alan çalışmaların incelenmesi sonucunda, yapay sinir ağlarının denetim alanında da büyük kolaylıklar sağlayacağı ve denetimin etkinliğini artırabileceği düşü- nülmüş ve bir model yardımıyla denetimin planlama aşamasında analitik inceleme tekniği olarak kullanımı ortaya konulmaya çalışıımıştır.

\subsection{Yapay Sinir Ağları}

Yapay sinir ağı, insan beyninin çalışma prensiplerinden esinlenilerek geliştirilmiş esnek bir matematiksel model olarak tanımlanabilmektedir (Wang vd., 2010:4769). Yapay sinir ağları, tecrübeden öğrenebilme yeteneğine sahip, yeni durumlara adapte olabilen, bunun yanında oldukça hızlı çalışan güçlü ve kıyaslanabilir bilgisayar sistemleridir. Yapay sinir ağlarında temel süreç elemanı nörondur. Her nöron ağırlıkla birleştirilmiş bir girdi setine sahiptir (Wang ve Takefuji, 1993: 12). Yapay sinir ağı modelinde üç önemli temel eleman dikkati çekmektedir. Bunlar; düğümlerin yapısı, ağın topolojisi ve ağın ağırlıklarını bulmak için kullanılan öğrenme algoritmasıdır. Yapay sinir ağı birbirleriyle bağlantılı ve paralel çalışabilen birçok düğümden oluşmaktadır. Bu düğümler birbirlerine ağırlıklar ile bağlıdır (Wang vd., 2010:4769).

Yapay sinir ağları sınıflandırma, kümeleme, tahmin gibi birçok alanda kullanılan oldukça etkili bir yöntemdir. Yapay sinir ağlarının en önemli özelliği öğrenebilme yeteneklerinin olmasıdır. Ağın öğrenebilmesi için ağa örnek bir veri seti sunulur. Temel süreç elemanları nöronlar, birbirlerine ağılıklarla bağlanmış durumdadırlar. Katmanlar içinde gruplandırılmış nöronların ağırlıkları sürekli düzeltilerek öğrenme işlemi gerçekleşir. Giriş katmanı nöronlardan oluşmaktadır ve girdiler dış ortamdan alınır. Çıkış katmanı da nöronlardan oluşur ve dış çevreyle iletişimi çıkış katmanı sağlar. Girdi katmanıyla çıktı katmanı arasındaki katmana ise saklı (gizli) katman denilmektedir. Saklı katman, girdi katmanı ve çıktı katmanı arasındaki bağlantıda bir kara kutu gibi davranır ve iki tabaka arasındaki ilişkiyi sağlar. Girdi katmanı ve çıktı katmanı arasında doğrusal olmayan bir ilişki varsa saklı katman çıktılardan genelleme yapabilmeyi kolaylaştırır (Efendigil vd., 2009:6699).

Geleneksel yöntemler, yanlış sonuçların elde edilmesi riski nedeniyle eksik ve/veya aşırı sapma içeren veriler için uygun değillerdir. Yapay sinir ağı yaklaşımı ise, verilere bağlı olmayıp; eksik, kısmen hatalı veya aşırı sapmalı verileri değerlendirebilir, hatta karmaşık ilişkileri öğrenebilir, genelleyebilir ve bu sayede daha önce hiç karşılaşmadığı sorulara kabul edilebilir bir hatayla cevap bulabilir. Bu özelliği nedeniyle yapay sinir ağları tahminleme de etkili bir yöntem olarak kullanılmaktadır (Özalp vd., 2003: 30).

Tahmin ve sınıflandırma problemleri için en yaygın kullanılan yapay sinir ağı türü çok katmanlı algılayıcılardır (multilayer perceptron). Çok katmanlı algı- 
layıcılar, girdi katmanı, çıktı katmanı ve bu iki katman arasında çeşitli sayıda ara katmanlardan oluşan ileri beslemeli bir yapıya sahip yapay sinir ağı çeşididir. Literatürde geri yayılımlı ağ (backpropagation network) olarak da bilinir. Çünkü bu ağ çeşidi öğrenme algoritması olarak geri yayılım algoritmasını kullanmaktadır (Hamzaçebi, 2011: 43). Bu öğrenme algoritması çok tabakalı bir sistem üzerinde çalışır. Giriş ve çıkış değişkenleri arasındaki ilişki doğrusal olmayan bir yapı içerdiğinden çıkışların genellemesini kolaylaştırır. Verilen bir girdi vektörü ileriye doğru bir çıktı vektörü üretir. Ağın ürettiği çıktı vektörü ile hedef çıktı vektörü arasında fark ağda geriye doğru yayılarak ağırlıklar düzeltilir. Söz konusu bu sürece öğrenme süreci denilmektedir (Koskivaara, 1996:6). Şekil 1'de çok katmanlı bir algılayıcı modeli görülmektedir.

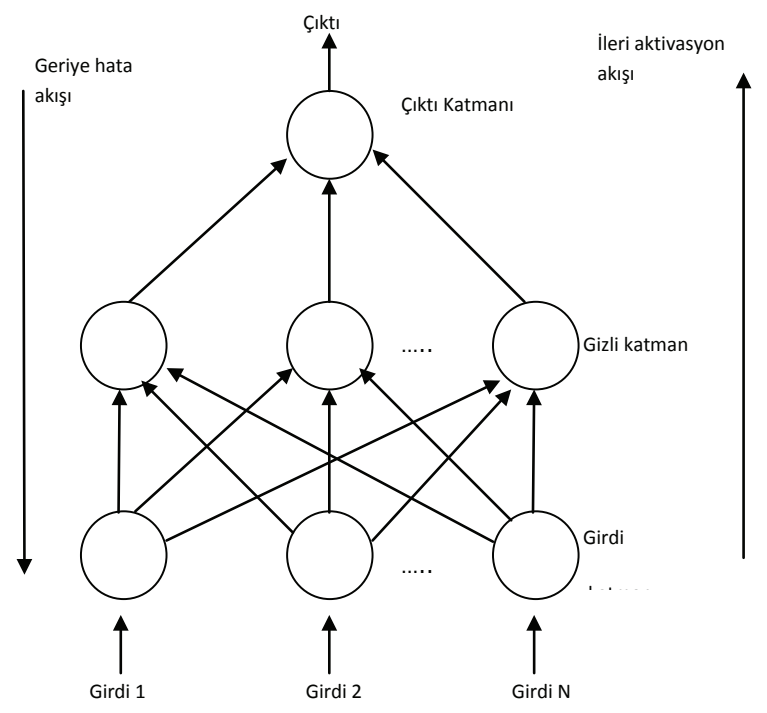

Şekil 1: Çok Katmanlı Algılayıcı Modeli ( Kaynak: Hamid ve lqbal, 2004:1118)

\section{UYGULAMA}

Bu çalışmada, Borsa İstanbul'da imalat sektöründe işlem gören bir işletmenin 2004 - 2012 yılları arasındaki üçer aylık denetimden geçmiş finansal tablolar kullanılmıştır. Çalışmada finansal tablolarda yer alan on farklı hesap kullanılarak, hesaplar arası ilişkileri gözlemlemek amacıyla zaman serisi analizi yapılmıştır. Çalışmanın amacı geçmiş gözlem değerlerinden yararlanılarak gelecekteki belirli bir dönemi tahmin etmektir. Çalışmada tahmin problemlerinde oldukça sık kullanılan çok katmanlı algılayıcı (multilayer perceptron) ileri beslemeli geri yayılımlı (feed forward backpropagation) ağ kullanılmıştır.

Çalışmada işletmenin; kısa ve uzun vadeli net ticari alacakları, kısa ve uzun vadeli toplam net ticari borçları, satış gelirleri, satılan mal maliyeti, brüt satış karı, pazarlama satış dağıtım gideri, şüpheli ticari alacaklar, ticari mal hesabı, maddi duran varlıklar (brüt) ve maddi duran varlıklara ait birikmiş amortisman olmak üzere 10 farklı hesap değişken olarak kullanılmıştır. Söz konusu değişkenlerin çalışma kapsamına alınmasında birbirleriyle olan ilişkisi etkili olmuştur. Bu kapsamda, satılan mal maliyetinde meydana gelecek bir artışın ticari mal alışlarından kaynaklandığı beklenmektedir. Ticari mal alışlarının peşin yapılmaması durumunda, bu artış ticari borçlar kaleminde de artışa neden olmaktadır. Bununla birlikte brüt satış karı kalemi, işletmenin satış gelirlerinden satılan ticari mal maliyetinin düşmesiyle bulunmaktadır. Pazarlama satış dağıtım giderleri de işletmenin ticari mal satışları ile paralel olarak ortaya çıkması nedeniyle genellikle satış geliri kalemi ile paralellik göstermektedir. Peşin satış yapmayan bir işletmede satış gelirlerindeki artışla birlikte ticari alacaklar kaleminde de artış beklenmektedir. Satış gelirinde artış olmamasına rağmen ticari alacaklar ve şüpheli ticari alacaklar kalemindeki artış, ya alacak tahsilatı ya da bu kalemlerin muhasebeleştirilmesiyle ilgili bir sorunun göstergesi olabilmektedir. Bunun yanında, maddi duran varlık ve bu varlık için ayrılan amortisman giderlerinin artış göstermesi sonucunda işletmenin satış gelirlerinde de bir artış olması beklenmektedir. Çünkü, yapılan maddi duran varlık yatırımına rağmen satış gelirlerinde hiç artış yaşanmıyorsa, gereksiz maddi duran varlık yatırımı yapıldığı düşünülmektedir. Bununla birlikte maddi duran varlık ve dolayısıyla onun için ayrılan amortisman giderinin muhasebeleştirilme sürecinde bir sorun olması da muhtemeldir. Çalışmada 10 değişkenin tercih edilmesinde bağımsız denetçilerle yapılan görüşmeler de etkili olmuştur.

Çalışmada AIC kriteri baz alınarak gecikme sayısı iki olarak belirlenmiştir. Bu bağlamda, gelecek dönemi tahmin etmek için ağın girdi katmanında iki gecikmeli ve bir gecikmeli değerleri bağımsız değişken olarak $\left(\mathrm{X}_{\mathrm{t}-2^{\prime}} \mathrm{X}_{\mathrm{t}-1}\right)$, çıkış katmanında ise gecikmesiz veri değerleri bağımlı değişken olarak $\left(Y_{t}\right)$ kullanılmıştır. 2004-2010 yılları eğitim verisi olarak kullanılmış, 2011-2012 yılları arası ise test verisi olarak kullanılmıştır. Bu veriler dikkate alınarak 2013 yılı ilk çeyreği tahmin edilmiştir. Şekil 2'de kullanılan ağ yapısı temsili olarak gösterilmiştir. 


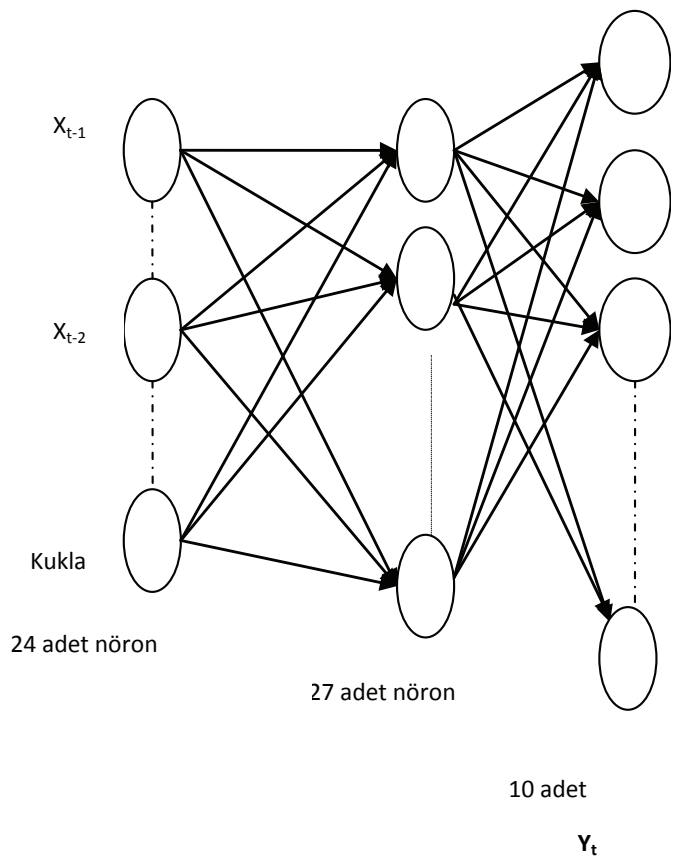

Şekil 2: Çalışmada Kullanılan Ağ Yapısı

Şekil 2'de görülen 3 katmanlı ağ yapısında, 10 adet değişkenin her birinin iki gecikmeli ve bir gecikmeli değerlerinin yanı sıra ilave edilen kukla değişkenler bağımsız değişken olarak girdi katmanında kullanılmıştır. Kukla değişkenlerin kullanılma sebebi, bağımlı değişkenler üzerinde mevsim etkisini görebilmektir. Kukla değişken, eğer nöron verinin olduğu çeyrek döneme karşılık geliyorsa 1, aksi takdirde 0 değerini almaktadır. Bu bağlamda kukla değişkenlerle birlikte girdi katmanında 24 adet nöron kullanılmıştır. Gizli katman sayısı ve bu katmandaki nöron sayısı belirlenirken çeşitli denemeler yapılmıştır. Bu denemeler yapılırken tahmin performans ölçümlerine bakılarak en iyi ağ yapısı belirlenmiştir. Bu ölçümler ne kadar küçükse problem kaliteli çıktılar üretecektir. Amaç, tahmin yapılırken hatayı mümkün olduğunca minimize edebilmektir. Dolayısıyla bu ölçümlerin en küçük olduğu ağ yapısı en iyi ağ yapısı olacaktır. Tahmin performans ölçümleri için literatürde en çok 1 numaralı formül RMSE (Hata Kareleri Ortalamasının Karekökü), 2 numaralı formül MAPE (Mutlak Hata Oranları Ortalaması) ve 3 numaralı formül MSE (Hata Kareleri Ortalaması) değerlerine bakılmaktadır (Zhang vd.,1998:500, Cho, 2003:328, De Lurgio, 1998:53). Bu ölçümler dikkate alınarak tek gizli katman ve bu katmandaki nöron sayısı ise 27 olarak belirlenmiştir. Çıktı katmanında ise 10 adet nöron (bağımlı değişken) bulunmaktadır. Oluşturulan ağlar değerlendirilirken tahmin performans ölçümleri küçük olan ağ tercih edilmiştir. Böylece en iyi performans gösteren ağ yardımıyla değişkenlerin ileriye yönelik tahmin değerleri elde edilmiştir. Bu ölçümlere göre, Witt ve Witt (2000) MAPE değerleri \%10'un altında olan tahmin modellerini "yüksek doğruluk" derecesine sahip, \%10 ile \%20 arasında olan modelleri ise "doğru tahminler" olarak sınıflandırmıştır. Benzer şekilde Lewis (2002), MAPE değerleri \%10'un altında olan modelleri "çok iyi", \%10 ile \%20 arasında olan modelleri "iyi", \%20 ile \%50 arasında olan modelleri "kabul edilebilir" ve \%50'nin üzerinde olan modelleri ise "yanlış ve hatalı" olarak sınıflandırmıştır. Ölçümlerin istatistiksel ifadesi aşağıda verilmiştir (Aktaran Çuhadar ve Kayacan, 2005:6).

$$
\begin{aligned}
& \text { RMSE }=\sqrt{\frac{\sum\left(y_{t}-\hat{y_{t}}\right)^{2}}{T}} \\
& M A P E=\frac{1}{T} \sum\left|\frac{y_{t}-\hat{y}_{t}}{y_{t}}\right| \times 100
\end{aligned}
$$

$$
M S E=\frac{\sum\left(y_{t}-\hat{y}_{t}\right)^{2}}{T}
$$

Burada;

$y_{t}=$ Gerçek gözlem değerleri,

$\hat{y}_{t}=$ Tahmin edilen değerleri,

$\mathrm{T}=$ Tahmin sayısıdır.

Çalışmada verilerin bir gecikmeli ve iki gecikmeli değerleri bağımsız değişken olarak kullanıldığı için her bir hesap için 2 adet veri kaybı olmuştur. Bu sebeple 26 veri öğrenme, 8 veri ise test periyoduna tabi tutulmuştur. Öğrenme periyodunda \%100 bir öğrenme sağlanmıştır.

Çalışmanın sonucunda teste tabi tutulan hesapların gerçek ve tahmin değerleriyle ilgili karşılaştırmalar yapılmıştır. Aşağıda çalışma kapsamında incelenen her bir hesap için gerçek değer ve tahmini değerlerini gösteren grafikler verilmektedir. 


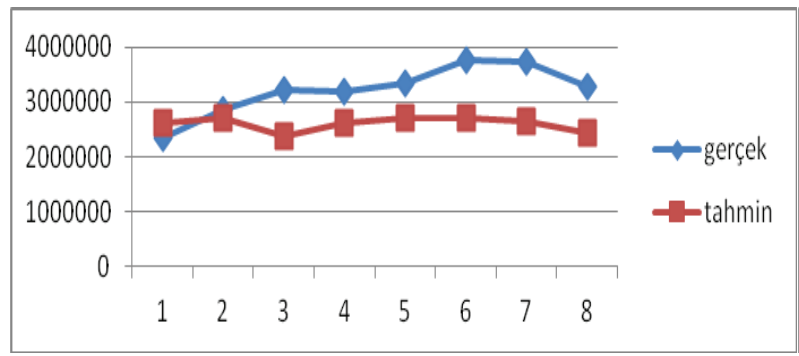

Şekil 3: Kısa ve Uzun Vadeli Toplam Net Ticari Alacaklar

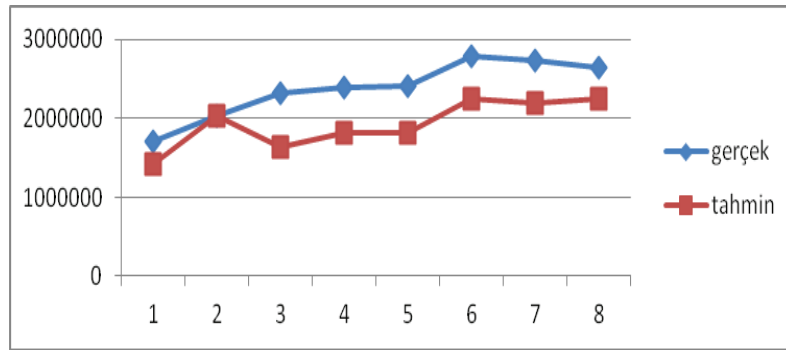

Şekil 5: Satış Gelirleri

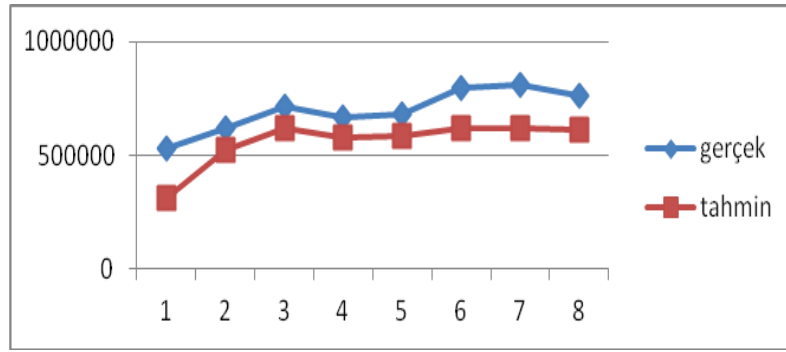

Şekil 7: Brüt Satış Karı

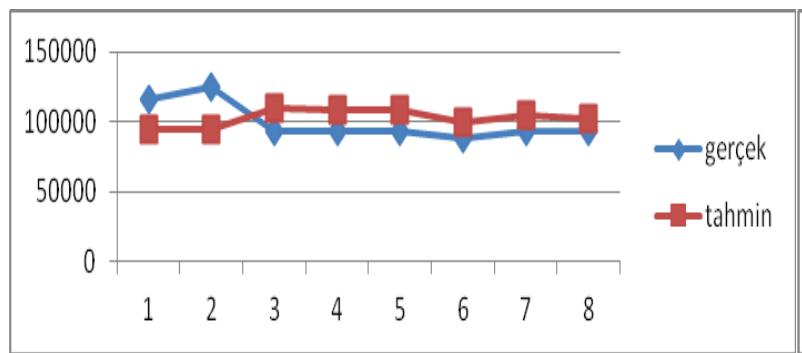

Şekil 9: Şüpheli Ticari Alacak

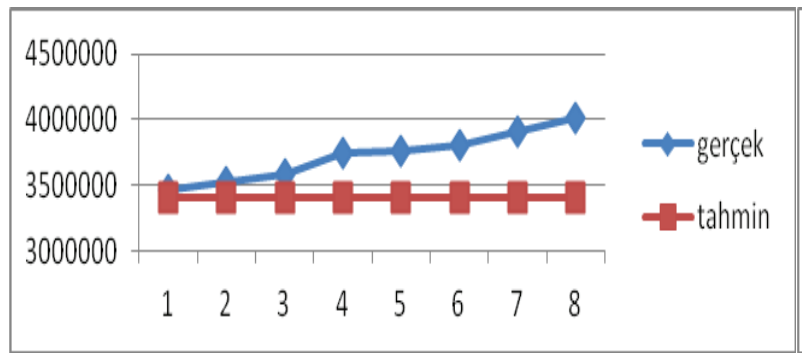

Şekil 11: Brüt Maddi Duran Varlıklar

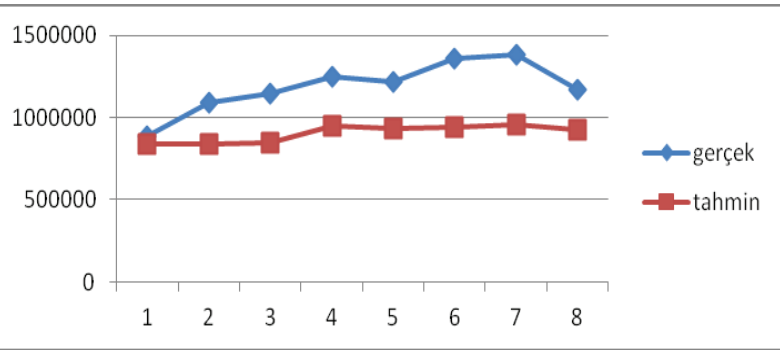

Şekil 4: Kısa ve Uzun Vadeli Toplam Net Ticari Borçlar

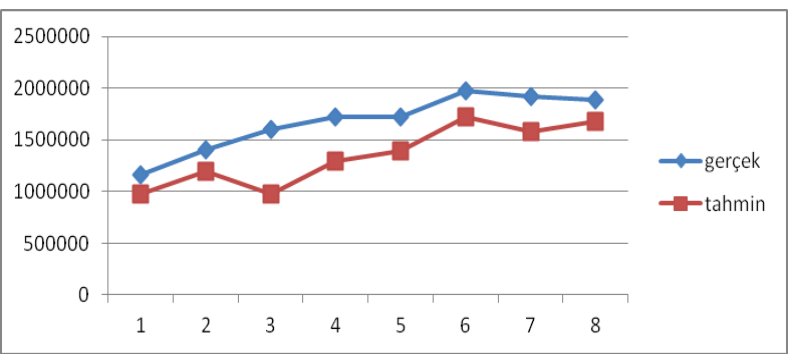

Şekil 6: Satılan Mal Maliyeti

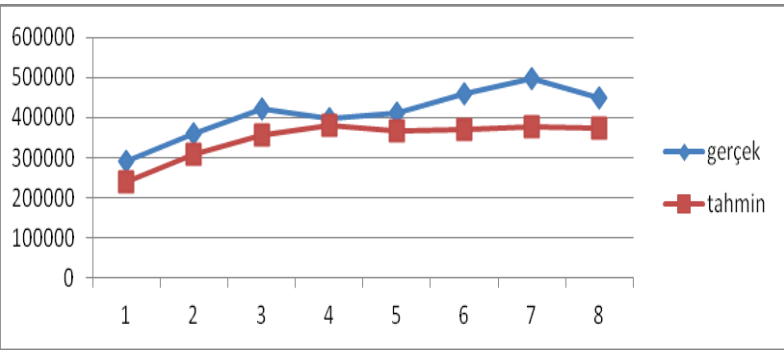

Şekil 8: Pazarlama Satış Dağıtım Giderleri

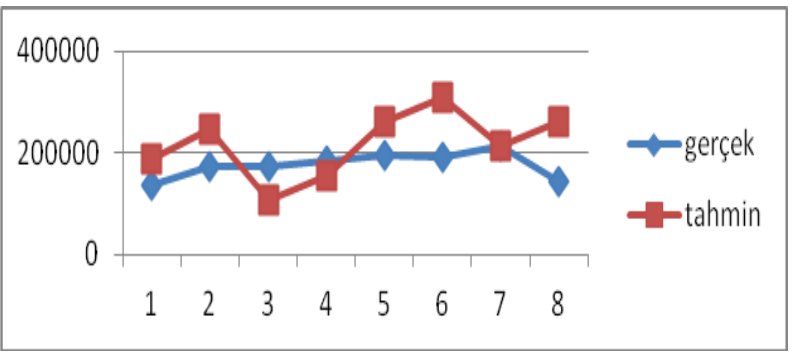

Şekil 10: Ticari Mallar

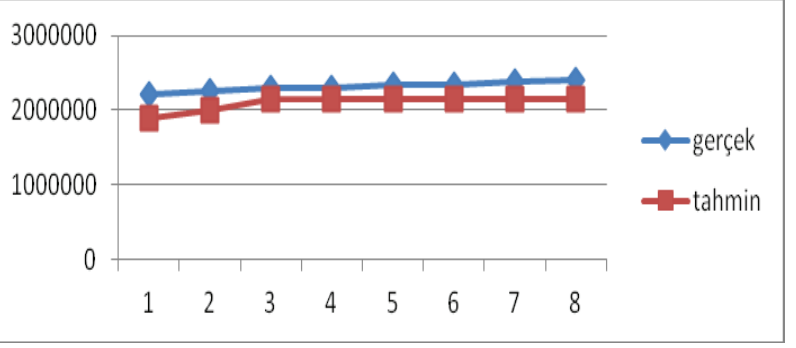

Şekil 12: Maddi Duran Varlıkların Birikmiş Amortismanı 
Tüm hesapların RMSE, MAPE ve MSE değerleri ise Tablo 2'de verilmektedir.

Tablo 2: Test Değerleri İçin Hesaplanan RMSE, MSE ve MAPE Değerleri

\begin{tabular}{|l|c|c|c|}
\hline \multicolumn{1}{|c|}{ DEĞişKENLER } & RMSE & MSE & MAPE \\
\hline $\begin{array}{l}\text { Kısa ve Uzun Vadeli Toplam } \\
\text { Net Ticari Alacaklar }\end{array}$ & 0,07607 & 0,00579 & 0,20577 \\
\hline $\begin{array}{l}\text { Kısa ve Uzun Vadeli Toplam } \\
\text { Net Ticari Borçlar }\end{array}$ & 0,03040 & 0,0009 & 0,22980 \\
\hline Satış Gelirleri & 0,04903 & 0,00240 & 0,18433 \\
\hline Satılan Mal Maliyeti & 0,03531 & 0,00125 & 0,19627 \\
\hline Brüt Satış Karı & 0,01485 & 0,00022 & 0,20488 \\
\hline $\begin{array}{l}\text { Pazarlama Satış Dağıtım } \\
\text { Gideri }\end{array}$ & 0,00716 & 0,00005 & 0,15621 \\
\hline Şüpheli Ticari Alacaklar & 0,01736 & 0,00030 & 0,15736 \\
\hline Ticari Mal Hesabı & 0,00752 & 0,00006 & 0,38970 \\
\hline Maddi Duran Varlıklar (Brüt) & 0,03628 & 0,00131 & 0,08261 \\
\hline Maddi Duran Varlık Bir. Amr & 0,02291 & 0,00052 & 0,09633 \\
\hline
\end{tabular}

Tablo 2'de görüldüğü üzere MAPE değerleri "çok iyi" ve "kabul edilebilir" seviyeleri arasında değişmektedir.

Çalışmada 2013 ilk çeyreği de tahmin edilmiştir. Çalışmanın sonlarına doğru 2013 ilk çeyrek dönemi açıklanmış böylece karşılaştırma yapılabilmiştir. Tablo 3'te 2013 ilk çeyrek dönemine ait gerçek ve tahmin değerleri ile mutlak yüzde hataları verilmiştir.

Denetim planlamasının amacı, denetim konusunu denetim sahalarına ayırmak, denetçileri denetim sahalarına görevlendirerek dağıtmak, her bir denetim sahasında uygulanması öngörülen denetim yöntem ve işlemlerini belirlemek ve denetim faaliyetlerini zamanlamaktır (Güredin, 2008:185). Dolayısıyla, denetçi bu süreç içerisinde müşteri işletme ile ilgili bir takım bilgiler edinmelidir. Bu bilgilerin edinilmesi için bazen işletmenin arşivi kullanılırken bazen de belirli teknikleri kullanarak işletme hakkında bilgi edinmeye çalışır. Çalışmada, söz konusu tekniklerden birisi olan yapay sinir ağları modeli kullanılarak işletme hakkında bilgi toplanması amaçlanmıştır. Bu bağlamda, Tablo 3'de görüldüğü üzere, işletmenin 2013 yılına ait ilk çeyreği için hesapların tutarları geçmiş dönem verileri kullanılarak tahmin edilmiştir. Tahmin edilen değerler işletmenin beyan ettiği değerlerle karşılaştırılmıştır. Bazı hesaplarda tahmin edilen tutar ile beyan edilen tutar arasındaki farkı çok az olmasına rağmen( örn,şüpheli ticari alacaklar vb.), bazı hesaplarda ise söz konusu farkın daha fazla olduğu görülmektedir. Bu bağlamda, denetçi, aralığın fazla olduğu alanlarla ilgili uygulayacağı denetim işlemlerinin kapsamını ve sayısını artırıp, oluşturulacak olan denetim programında söz konusu alanlara ağırlık verirken, aralığın düşük olduğu hesapları ise göz ardı edebilecektir. Bu kapsamda Şekil 13'te 2013 ilk çeyreğine ilişkin tahmin ve gerçek değerlerin grafiksel gösterimi verilmiştir.

Tablo 3: Geleceğe Yönelik Tahmin (2013 İlk Çeyreği)

\begin{tabular}{|l|c|c|c|}
\hline \multicolumn{1}{|c|}{ DEĞişKENLER } & GERÇEK & TAHMiN & $\begin{array}{l}\text { Mutlak } \\
\text { Yüzde Hata } \\
\text { (MAPE-\%) }\end{array}$ \\
\hline $\begin{array}{l}\text { Kısa ve Uzun Vadeli } \\
\text { Toplam Net Ticari } \\
\text { Alacaklar }\end{array}$ & 3355423 & 2812620 & 16,17690 \\
\hline $\begin{array}{l}\text { Kısa ve Uzun Vadeli } \\
\text { Toplam Net Ticari } \\
\text { Borçlar }\end{array}$ & 1251513 & 916257,5 & 26,78802 \\
\hline Satış Gelirleri & 2430171 & 1918474 & 21,05603 \\
\hline Satılan Mal Maliyeti & 1691658 & 1498780 & 11,40171 \\
\hline Brüt Satış Karı & 738513 & 576115,2 & 21,98984 \\
\hline $\begin{array}{l}\text { Pazarlama Satış } \\
\text { Dağıtım Gideri }\end{array}$ & 432862 & 370561,8 & 14,39262 \\
\hline $\begin{array}{l}\text { Şüpheli Ticari Alacak } \\
\text { Ticari Mal Hesabı }\end{array}$ & 92615 & 99795,9 & 7,75350 \\
\hline $\begin{array}{l}\text { Maddi Duran Varlıklar } \\
\text { (Brüt) }\end{array}$ & 4053507 & 251132,2 & 22,83305 \\
\hline $\begin{array}{l}\text { Maddi Duran Varlık } \\
\text { Birikmiş Amortisman }\end{array}$ & 2464761 & 2141978 & 13,09590 \\
\hline
\end{tabular}

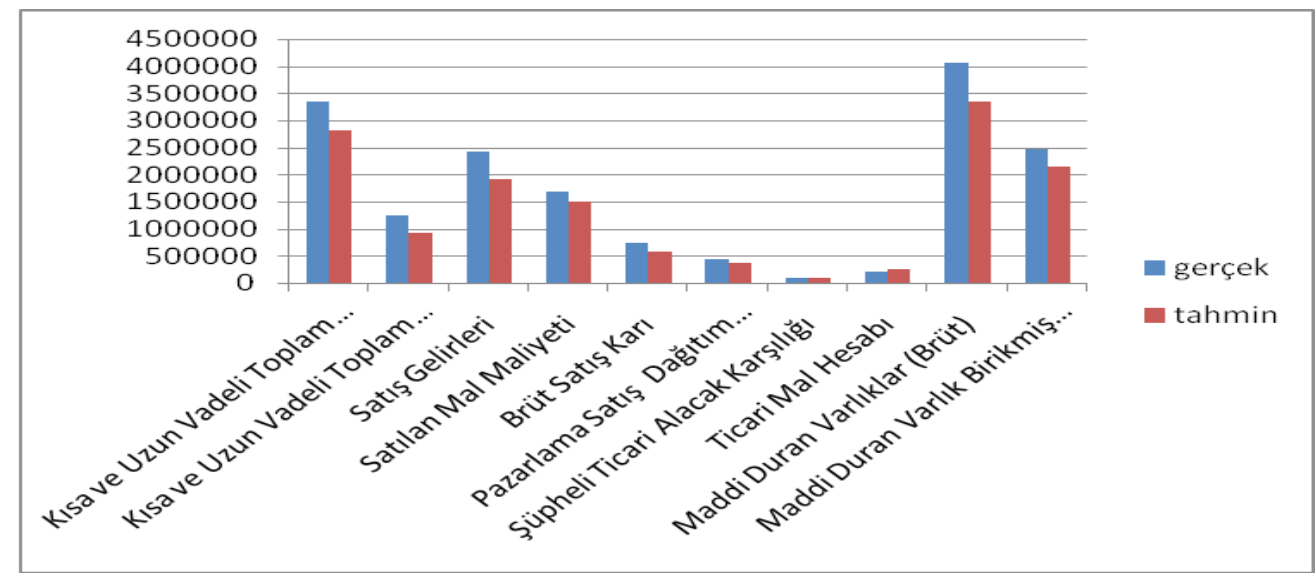

Şekil 13: 2013 İlk Çeyrek Dönem Tahmin ve Gerçek Değerlerinin Grafiği 


\section{SONUÇLAR}

Son yıllarda işletmelerin yapısal olarak karmaşıklaşması ve teknolojik gelişmeler denetçilerin denetim için harcayacakları süreci uzatmış ve finansal tablolarda var olan hata ve hile tespitini de zorlaştırmıştır, tüm bu gelişmeler denetim sürecinde farklı analitik inceleme tekniklerinin kullanılmasını gündeme getirmiştir.

Bu çalışmada, yapay sinir ağı yönteminin denetimin planlama aşamasında analitik inceleme tekniği olarak nasıl kullanılacağı ve ne gibi sonuçlar ortaya koyacağı gösterilmektedir. Bu bağlamda, Borsa İstanbul'da İmalat sektöründe işlem gören bir işletmenin Mart 2004-Aralık 2012 dönemine ait denetimden geçmiş finansal tablo verileri kullanılmıştır. Söz konusu verilerden 2004-2010 yılları eğitim verisi olarak, 2011 ve 2012 yılları ise test verisi olarak kullanılmıştır. Bu bağlamda modelin, test verisi olan 2011 ve 2012 yıllarına ait hesapların hata kareleri ortalamasının karekökü (RMSE), hata kareleri ortalaması (MSE) ve mutlak hata oranları ortalaması (MAPE) olarak bilinen tahmin performans ölçümleri hesaplanmıştır. Bu değerler ne kadar sıfıra yakınsa ortaya konulan tahminin o derece iyi olduğu söylenebilir. Bu bağlamda, tüm hesaplar için RMSE değerleri 0,00716 ile 0,07607 arasında, MSE değerleri 0,00005 ile 0,00579 arasında ve MAPE değerleri ise 0,08261 ile 0,3897 arasında değişmektedir. Dolayısıyla bu değerlerin sıfıra yakın olması ortaya konulan modelin güçlü olduğunun göstergesidir denilebilir. Literatüre göre, MAPE değerlerine bakılarak tüm hesaplar açısından modelin "çok iyi", "iyi" ve "kabul edilebilir" tahminler yaptığı görülmüştür. Bununla birlikte, çalışmanın hazırlandığı dönemde henüz açılanmamış olan 2013 Mart dönemine ait hesap bakiyeleri için de geliştirilen yapay sinir ağı modeli kullanılarak tahminleme yapılmıştır. 2013 yılının ilk çeyreğine ait finansal tabloların borsada yayınlanması ile birlikte modelin yaptığı tahminler yayınlanan hesap bakiyeleri ile karşılaştırılmıştır. Tablo 3'de görüldüğü üzere tahmin edilen değerler ile işletme tarafından beyan edilen değerlerin bazı hesaplarda birbirine çok yakın iken bazı hesaplarda aralığın arttığı görülmektedir.
Denetim planlamasının önemli aşamalarından biri önemlilik derecesinin ve denetim risk düzeyinin belirlenmesidir. Denetçi denetim çalıșmalarında mali tabloları etkileyebilecek tüm yanlışlıkları değil, önemli yanlışııkları ortaya çıkartmalıdır. Denetim riski ise, mali tablolarda önemli yanlışlık olduğu halde, denetçinin mali tabloların doğru olarak sunulduğu sonucuna varması ve olumlu görüş bildirmesi olasılığıdır (Selimoğlu vd., 2008:87). Önemlilik düzeyinin ve denetim riskinin belirlenmesinde en büyük faktör denetçinin sahip olduğu bilgi ve tecrübedir (Usul, 2013:85).

Önemlilik düzeyi yüksek ise denetim riski düşük, önemlilik düzeyi düşük ise denetim riski düşüktür. Denetçi, denetim planlama aşamasında öncelikle denetim riskini değerlendirmeli, daha sonra ise önemlilik derecesini belirleyerek toplanması gereken denetim kanıtlarının türünü, zamanını ve kapsamını kararlaştırmalıdır (Güredin, 2008:235).Her bir hesap kalemi için ayrı bir önemlilik sınırı belirlenmelidir (Selimoğlu vd., 2008.87). Bu bağlamda çalışmada, hesaplar için tahmin edilen tutarlar ile işletme tarafından beyan edilen tutarlar arasındaki farkın derecesi, denetim planlama aşamasında hem önemlilik derecesinin hem de denetim riskinin belirlenmesini etkilemekte, denetim riskinin ve önemlilik düzeyinin doğru tespiti denetim sürecinin de kalitesini artırmaktadır. Tablo 3 'de hesaplar için mutlak hata yüzdeleri verilmiştir. Buna göre, Kısa ve uzun vadeli ticari borçlar, brüt satış karı ve satış gelirleri ve ticari mal hesabı için hesaplanan mutlak hata yüzdeleri \%20'nin üzerinde iken, diğer hesaplar için ise mutlak hata yüzdeleri \%20'nin altında bulunmaktadır. Bu bağlamda denetçi özellikle mutlak hata yüzdeleri \%20'in üzerinde olan hesaplar için ayrıntılı inceleme başlatacak ancak özellikle mutlak hata yüzdeleri \%10'unun altında kalan hesapları göz ardı edebilecektir. Böylece denetçi için büyük ölçüde bir zaman tasarrufu sağlanacak ve denetim riski en aza indirilerek denetim sürecinin kalitesi artırılacaktır.

Bundan sonra yapılacak çalışmalarda, denetimin farklı aşamalarında da yapay sinir ağı modelinin kullanılabileceği düşünülmektedir. 


\section{KAYNAKLAR}

ACFE, (2010) "Report To The Nations On Occupational Fraud and Abuse" http://www.acfe.com/rttn/rttn2010.pdf, (05.07.2013)

Arens, A., Ejder, R. ve Beasley, M. (2011) Auditing and Assurance Services, Prentice Hall, Fourteenth Edition: 221.

Bilge, U. (2008) “Tipta Yapay Zeka ve Uzman Sistemler” Tıp Bilişimi 4. Ulusal Tıp Bilişimi Kongresi, Antalya.

Bozkurt, N. (1998) Muhasebe Denetimi, 2. Bask1, Alfa Yayınları.

Busto, B. ve Weinberg, R. (1998) “Using Benfrod's Law and Neural Networks As a Review Procedure" Managerial Auditing Journal, 13(6): 356-357.

Chan, HJ., Huang, SY. ve Kuo, C.L. (2009) “Using The Artifical eural Network To Predict Fraud Ligition: Some Empirical Evidence From Emerging Markets" Expert System With Applications, 36:1478-1484.

Chen, W.S., Du, Y.K. (2009) "Using Neural Networks and Data Mining Techiques for the Financial Distress Prediction Model" Expert System With Applications, 36:4075-4086.

Cho, V. (2003) "A Comparison Of Three Different Approaches To Tourist Arrival Forecasting” Tourism Management, 24: 323-330.

Çabuk, A. ve Lazol, İ. (2008) Mali Tablolar Analizi, 5. Baskı, Ankara, Nobel Yayınları.

Çuhadar, M. ve Kayacan, C. (2005) "Yapay Sinir Ağları Kullanılarak Konaklama İşletmelerinde Doluluk Oranı Tahmini: Türkiye'deki Konaklama İşletmeleri Üzerine Bir Deneme" Anatolia: Turizm Araştırmalar Dergisi, 16(1):24-30.

Davutyan, N. ve Kavut, L. (1997) “Bağımsız Denetimde Müşteri Kabul Riskinin Veri Zarflama Analizi Yoluyla Ölçülmesi” IMKB Dergisi, 9: 33-87.

De Lurgio, A.S. (1998) Forecasting Principles And Applications, Singapore, Irwin McGraw-Hill.

Dönmez, A. ve Ayten, E. (2011) "Bağımsız Denetim Sürecinde Analitik İnceleme Prosedürleri: Türkiye'de SPK'dan Yetki Almış Denetim Firmaları Üzerine Bir Araştırma” Bilgi Türk Sosyal Bilimler Dergi, (56):121-142.

Efendigil, T., Önüt, S. ve Kahraman, C. (2009) "A Decision Support System For Demand Forecasting With Artificial Neural Networks And Neuro-Fuzzy Models: A Comparative Analysis" Expert Systems with Applications, 36: 6697-6707.
Etherdig, H.L., Siriram, R.S. ve Hsu, H.Y.K. (2000) "Acomprasion of Selected Artifical Neural Networks that help Auditors Evaluate Client Financial Viability" Decision Sciences,31(2): 531-550.

Gaganis, C., Pasiouras, F. ve Daumpos, M. (2007) "Probabilistic Neural Networks For The Identification" Expert System With Applications, 32:114-124.

Gürbüz, H. (1995) Muhasebe Denetimi, 4. Baskı, Eskişehir, Bilim Teknik Yayınevi.

Güredin, E. (2008) Denetim ve Güvence Hizmetleri, 12. Baskı, İstanbul, Arıkan Yayınları.

Hamid, S.A. ve Iqbal, Z. (2004) "Using Neural Networks For Forecasting Volatility Of S\&P 500 Index Futures Prices" Journal of Business Research, 57: 1116-1125.

Hamzaçebi, C. (2011) Yapay Sinir Ağları, Bursa, Ekin Yayınevi.

Huss, H.F., Jacobs, F.A ve Patterson, D.M. (2000) "An Integrative Model of Risk Management in Auditing" American Business Review, 18(2):113-122.

Kepekçi, C. (2004) Bă̆ımsız Denetim, İstanbul, Avcıol Basım Yayın.

Krambia, M., Christodoulou, C. ve Agathocleous, M. (2010) "NEURAL Networks: The Panacea In Fraud Detection" Managerial Auditing Journal, 25(7): 659-678.

Koskivaara, E. (1996) "Artificial Neural Network Models for Predicting Patterns in Auditing Monthly Balances" Turku Centre for Computer Science, TUCS Technical Report No 67.

Koskivaara, E. (2004) "Artificial Neural Networks in Analytical Review Procedures", Managerial Auditing Journal, 19(2): 191-223.

Kutlu, B. ve Badur, B. (2009) "Yapay Sinir Ağları ve Borsa Endeksi Tahmini” Yönetim Dergisi, 63: 25-40.

Küçükkocaoğlu, G., Benli, Y.K. ve Küçüksözen, C. (2009) "Finansal Bilgi Manipülasyonunun Tespitinde Yapay Sinir Ağı Modelinin Kullanımı” IMMKB Dergisi, 36.

Okab, R. ve Taha, H. (2012) "The Possibility of Using Artificial Neural Networks in Auditing-Theoritical Analytical Paper" European Journal of Economics, Finance and Administrative Sciences, $47: 43-56$.

Özalp, A. ve Anagün, S. (2003) "Yapay Sinir Ağı Performansına Etki Eden Faktörlerin Analizinde Taguchi Yöntemi: Hisse Senedi Fiyat Tahmini Uygulaması" İstatistik Araştırma Dergisi, 2(1): 29-45. 
Pourheydari, O., Nezamabadi-Pour, H. ve Aazami, Z. (2012) "Identifying Qualified Audit Opinions By Artificial Neural Networks" African Journal of Business Management, 6(44): 11077-11087.

Samaha, K. ve Hegazy, M. (2009) "Empirical Inverstigation of The Use Of ISA 520 Analytical Procedures Among Big 4 Versus Non-Big 4 Audit Firms In Egypt" Managerial Auditing Journal, 25(9): 882-911.

Selimoğlu, S.K. ve Uzay, Ş. (2008) Muhasebe Denetimi, Ankara, Gazi Yayınları.

TUDESK (2008) Uluslararası Denetim ve Güvence Standartlar, Uluslar arası Denetim Standardı 520, Ankara, TURMOB Yayınları.

Puttick,G., Sandy Van Esch, S. ve Van Esch, S.D. (2008) The Principles and Practice of Auditing, Jute and Company.

Usta, Ö. ve Uçma, T. (2011) "Hileli Finansal Raporlamada Bağımsız Denetçi Sorumluluğunun Belirlenmesine Yönelik Yapısal Eşitlik Modeli Uygulaması" Muhasebe ve Denetime Bakı̧ Dergisi, 34:13-38.

Usul, H. (2013) Türkiye Finansal Raporlama Muhasebe Standartları Uygulamalı Bă̆ımsız Denetim, Ankara, Detay Yayıncilı.
Wang, J. ve Takefuji, Y. (1993) Neural Networks In Design and Manufacturing, Singapore, World Scientific Pub.

Wang, S., Dong, X. ve Renjin Sun, R. (2010) "Predicting Saturates Of Sour Vacuum Gas Oil Using Artificial Neural Networks And Genetic Algorithms” Expert Systems with Applications, 37:4768-4771.

Yılancı, F. M., Yıldız, B. (2008) "Denetimde Kontrol Riskinin Belirlenmesi: Yapay Sinir Ağı Yaklaşımı” İktisat, $\dot{I}_{3}$ letme ve Finans Dergisi, 23(273): 119-132.

Zhang, G. ve Hu, M.Y. (1998) "Neural Network Forecasting of the British Pound/US Dollar Exchange Rate" Omega Int. J. Mgmt. Sci, 26(4): 495-506.

Padilla and Company LLP, (2013) "Analytical Review Importance and Risks"

http://www.padillacpa.com/index.php?option=com content \&view = article \&id=24: analytical-revie, (19.03.2013)

Şirin, M. (2014) "Uluslar arası Denetim Standartları Çerçevesinde Denetim Kanıtları, Kanıt Toplama Teknikleri ve İstatistiki Örnekleme Yöntemleri”, www.hazine. org.tr/tr/images/uluslararasi\%20denetm\%20standartlari. pdf, (14.04.2014) 